\title{
A Sociological View on Designing a Sustainable Online Community for K-12 Teachers: A Systematic Review
}

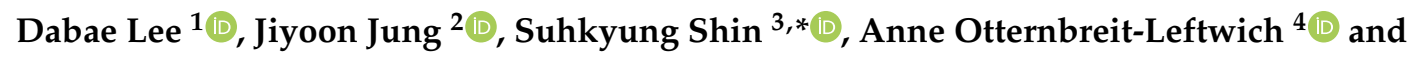 \\ Krista Glazewski ${ }^{4}$ (1) \\ 1 Department of Instructional Technology, Kennesaw State University, Kennesaw, GA 30144, USA; \\ dlee159@kennesaw.edu \\ 2 Leadership, Technology \& Workforce Development, Valdosta State University, Valdosta, GA 31698, USA; \\ jijung@valdosta.edu \\ 3 Department of Education, Hanyang University, Seoul 04763, Korea \\ 4 Instructional Systems Technology, Indiana University, Bloomington, IN 47405, USA; \\ aleftwic@indiana.edu (A.O.-L.); glaze@indiana.edu (K.G.) \\ * Correspondence: suhkshin@hanyang.ac.kr
}

Received: 29 October 2020; Accepted: 20 November 2020; Published: 22 November 2020

check for updates

\begin{abstract}
As a way to support teachers' professional development activities and build communities of practice for teachers, education researchers and practitioners have put considerable effort into building an online learning community for $\mathrm{K}-12$ teachers to create a venue to facilitate teachers' joint knowledge construction. However, a substantial number of such online communities have failed due to lack of participation of members. Therefore, it is critical to understand how to design a sustainable community that fulfills members' needs and elicits active participation of members. In this literature review, we adopted a sociological framework to investigate how to create a sustainable online community. This framework suggests that the sustainability of a community comes from individual members' three types of commitments: instrumental, affective, and moral commitments. Such commitments are results of members' cognitive, cathectic, and evaluative processes and lead to membership retainment, cohesive relationships, and socially regulated participation. Using this framework, we conducted a systematic literature review on online teacher community articles published from 1990 to 2018. Our findings provide insights on factors associated with teacher members' instrumental, affective, and moral commitment to an online community. Based on these findings, we further provide design suggestions to build a sustainable community for teachers.
\end{abstract}

Keywords: online community; professional development; sustainability; community of practice

\section{Introduction}

As a way to promote teachers' effectiveness and social engagement, education researchers and practitioners have put considerable effort into building an online learning community for K-12 teachers. These online communities are a form of communities of practice [1], where teachers informally share their understanding of their profession, explore new teaching methods, discuss a variety of personal and professional issues, and co-construct their knowledge in teaching and learning [2,3].

Researchers have found well-designed professional teacher communities to be effective in promoting student-centered teaching practices and associated with improved achievement scores over time [1]. These communities also provide more convenient and appealing just-in-time professional development opportunities for teachers, compared to formal professional development activities 
(e.g., taking courses, attending on-site professional conferences) that may conflict with their work schedule [4].

However, a number of professional communities have withered due to lack of members' participation [5-7] and reported lack of participation as a major reason of failure of their communities. Since prolonged participation is essential in building a community of practice [1], there is a need to better understand how to promote and sustain active participation in an online professional community.

Existing research on online communities has drawn from various theoretical and analytical models [8]. In a systematic review of 52 studies on online communities [9], Lantz-Andersson et al. found that Community of Practice [1] was used most frequently as a theoretical framework, followed by sociocultural perspectives [10], and Grounded Theory [11]. While these frameworks guide researchers' inquiries on facilitating learning and social interaction, they provide little guidance as to how to design a sustainable community.

In this paper, we apply a theory from sociology, a field that has long studied the notion of sustainability of a community, to conduct a literature review on designing a sustainable online teacher community. Kanter's theory of commitment [12] explains that sustainability comes from individual members' commitment to the community. It posits that a community needs to go through commitment building processes to sustain itself. It has been continuously used in various contexts to study commitment and sustainability of a relationship such as employees' commitments to an organization [13,14], customers' loyalty to certain brands [15], and the relationship between manufacturers and distributors [16]. This framework may highlight aspects of online teacher communities that contribute to strengthening members' various commitments.

\section{Kanter's Commitment-Based Community Building Framework}

Kanter defines commitment as "a person's willingness to carry out the requirements of a pattern of social action, because she sees it as stemming from her own basic nature" [12]. A person is committed to a social group to the extent that the person sees it as closely aligned to his fundamental needs [17]. If the members' commitments are ensured, a small community can sustain itself. She conceptualized three types of commitment: instrumental, affective, and moral commitments.

\subsection{Instrumental Commitment from the Cognitive Process}

Instrumental commitment, one's cognitive willingness to continue participation, is determined by individual members' cognitive processes [15]. Members continuously engage in a cognitive process of assessing the potential rewards (cognitive benefits) and costs of participating in the community (money, effort, time) or leaving the community. The positive outcome from this process is expected to result in their instrumental commitment that leads to retention, members continuing to staff the community and carry out their roles [16]. Therefore, identifying what members need from a community is a fundamental step to making an online community successful [17]. If a teacher member finds a community providing knowledge capital that is more valuable than the time and effort she needs to spend to gain that capital, or if she finds leaving the community is more costly than staying in it, she will be instrumentally committed and remain in the community as a member.

\subsection{Affective Commitment from the Cathectic Process}

Affective commitment refers to meaningful emotion-laden social connections with other members [12]. This holds group members together, determining group cohesiveness [17]. Group cohesiveness denotes the ability of people to stick together to develop the mutual attraction and collective strength [17]. Affective commitment is determined through a cathectic process. This refers to the process in which members assess the extent to which they share common feelings with other members. The more members affectively bond with another and identify themselves within the collective whole, the more cohesive the community becomes. A cohesive group can withstand threats to its existence [17]. 


\subsection{Moral Commitment from the Evaluative Process}

Moral commitment is a connection with a member's set of beliefs, values, or ethical demands to those of the community. A community with morally committed members tends to be socially regulated-be less deviant and more active in participation [17]. According to Kanter, "social control involves the readiness of people to obey the demands of the system, to conform to its values and beliefs and take seriously its dictates" [17] (p. 67). Moral commitment is determined as members engage in an evaluative process of examining the norms and beliefs of the system and determining its compatibility to their own. In order to induce moral commitment, the community's norms and values should be portrayed as appropriate and valuable to members. Figure 1 summarizes the framework.

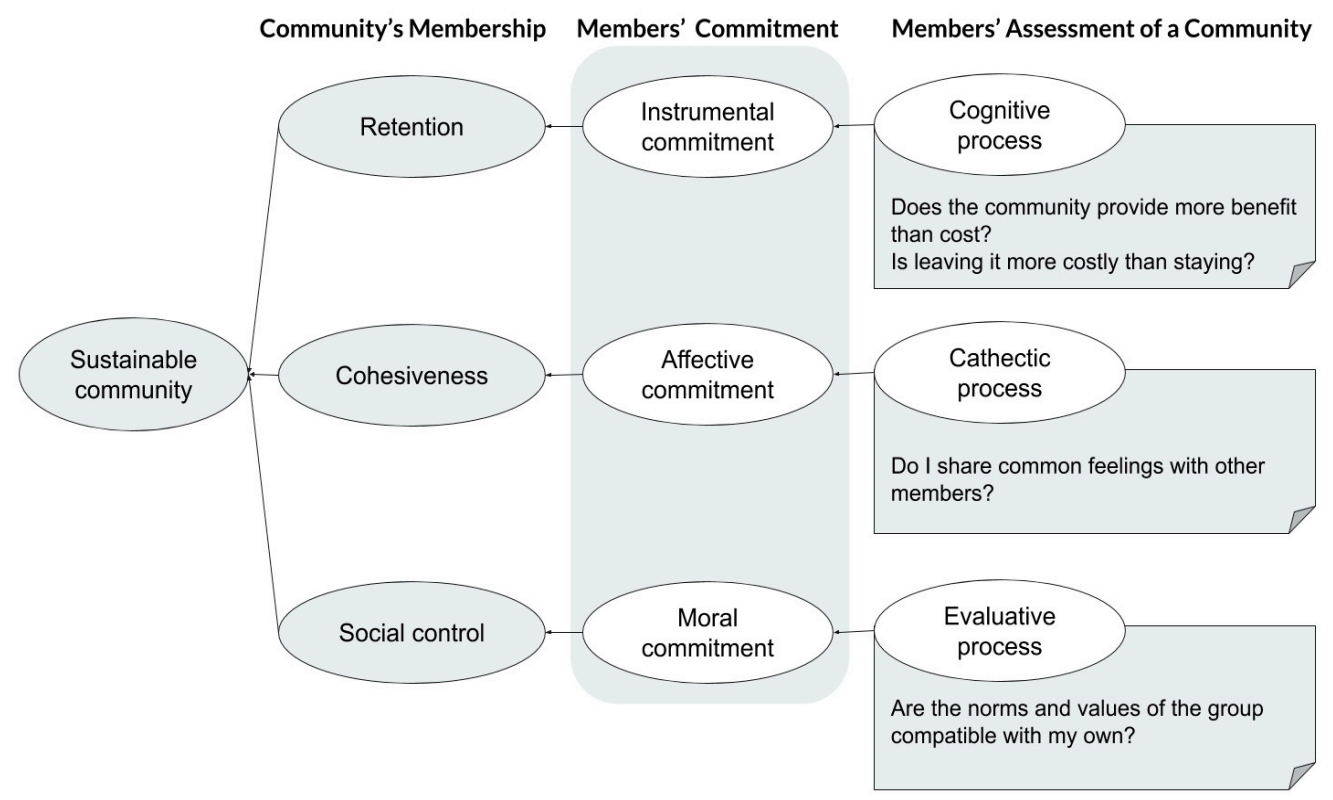

Figure 1. Kanter's Framework.

\subsection{Total Commitment}

Kanter demonstrated that the three types of commitment are conceptually and empirically distinctive with some examples [17]. A worker may take a better job although his best friends work in his previous workplace. He may be more affectively committed to the previous workplace yet perceive more instrumental benefits in his current workplace. A prisoner may form close relationships with fellow prisoners or guards, but he wishes to leave the system as early as possible. The prisoner may have developed high affective commitment but low instrumental or moral commitment.

Although these three types are distinctive, Kanter argued that they are mutually reinforcing and multiply determined [17]. In an ideal community with all three commitments emphasized, the more the members are emotionally attached (group cohesion), the more they wish to remain in the community (retention), and the more they support the values of community (social control). Research revealed relationships between these factors. Allen and Meyer found that group cohesiveness and social control were related in three different types of organizations [13]. Hodes et al. found that, in a teacher community, a sense of shared values (moral commitment), gave the group a sense of belonging (affective commitment) [18]. It was also reported that a sense of belonging (affective commitment) led to more active knowledge sharing and collaboration, strengthening instrumental commitment $[18,19]$. Therefore, Kanter argued that communities with members' total commitment should be more sustainable than those without it [17]. 


\section{Methods}

This study aims to provide guidelines for designing a sustainable online teacher community by systematically reviewing current literature based on Kanter's framework. Two research questions guided the inquiry: (1) how each type of commitment is characterized in teachers' communities and (2) how to design a sustainable online community for teachers.

\subsection{Article Search}

EBSCOhost Boolean search was performed on six databases [Academic Search Premier, Education Resources Information Center (ERIC), Business Source Complete, Primary Search, PsycARTICLES, and Professional Development Collection] using the following search phrase: "teacher online community" OR "teacher mobile collaboration" OR "teacher social networking" OR "social networking teacher collaboration" OR "online collaboration instructors" OR "online teacher collaboration" OR "teacher collaboration" OR "teacher collaboration tools" OR "teacher collaboration technology". The search was limited to scholarly, peer-reviewed journal articles published between January 1990 and November 2020, and limited to articles published in academic journals, journals, and reports which were written in English. The search resulted in 6301 articles.

Titles and abstracts of the searched articles were reviewed by three authors for initial screening, based on the following inclusion criteria: (1) research on online communities including social networking sites and (2) research related to in-service or pre-service teachers. They included articles for which abstracts provided insufficient information as to the inclusion criteria for this initial screening. A total of 135 articles were selected. The three authors individually reviewed the articles and noted whether to include. The first author reviewed the notes, abstracts, and full text to gain sufficient information, and 92 articles were excluded. Exclusion criteria follow with the numbers of articles excluded: not empirical studies or literature reviews (30), offline communities or online courses rather than permanent online communities (26), not teachers' communities (12), research with different focus such as an administrator's work (5), and not voluntary participation (3). Finally, 43 articles remained for full analysis.

\subsection{Article Review}

The three authors discussed Kanter's framework and examples several times before reviewing the articles to have a common understanding. They reviewed two articles together to reach consensus on how to code the content of the articles and prepare the review template. The articles were divided among the three authors for independent reading and analysis.

To answer the two research questions, they made descriptive notes on (1) instances that characterize Kanter's three commitment types (instrument, affective, moral) (2) design approaches or strategies used for possible design suggestions. After all articles were analyzed, the first author reviewed the descriptive notes and noted those that unclearly corresponded to the three types. The three authors met to discuss the discrepancies and re-read the articles until the discrepancies were resolved.

\section{Findings}

Table 1 shows our coding results. More than half of articles focused on instrumental commitment or design strategies. Fewer articles covered members' affective and moral commitments. Appendix A lists the last names of the first authors, publication years, and titles of the articles selected. Appendix B shows analysis results of individual articles. The community sizes varied from 11 to 100,000 members at the time of study. As a whole, the 43 articles studied 44 online communities for teachers. There were six international communities and 36 communities from 12 countries. More detailed information about the communities is provided in Appendix C. 
Table 1. Coded categories and numbers of articles.

\begin{tabular}{ccccc}
\hline Category & Instrumental & Affective & Moral & Design \\
\hline \# of Articles & 26 & 13 & 9 & 23 \\
$\%$ & $67 \%$ & $33 \%$ & $23 \%$ & $59 \%$ \\
$\begin{array}{c}\text { Community Size } \\
\text { (Min-Max) }\end{array}$ & $20-100,000$ & $48-100,000$ & $20-20,000$ & $11-100,000$ \\
\hline
\end{tabular}

\subsection{Instrumental Commitment}

In order to induce instrumental commitment, perceived rewards should be larger than perceived costs in the individual members' cognitive process [17]. Major rewards perceived by teachers were knowledge capital and social networks that provide ongoing professional development opportunities to keep current in the profession and enhance professional practice [20-23]. Trust and Horrocks [24] found that access to various resources and connections between people with different expertise allowed members in the Discovery Education Network (DEN) to personalize learning based on their interests, needs, and goals. They could drive their own learning by leveraging the resources and the network in DEN rather than "wait to be professionally developed by an outside expert" (p. 111).

\subsubsection{Knowledge Capital}

Teachers perceived curricular and technological resources for professional development and improvement in teaching as major rewards to being involved in an online community [25]. In their systematic review, Lantz-Andersson et al. noted that more than half of their reviewed studies stated that members viewed online communities as a means to gather and share information about teaching-related topics [9]. In another systematic review, Vescio et al. examined the relationship between sustained and intensive professional development of teachers and student achievement gains [26]. The discussion highlights that the knowledge capital in a professional learning community should be most relevant to academic achievement of the students. Our review suggests that types of knowledge capital pursued by teachers center on curricular and technological resources.

Curricular resources. Finding and sharing various curricular resources was most frequently discussed in the literature. These resources included lesson ideas or plans, best practices, teaching strategies, student activities [22,26-31], and teaching advice such as solutions to classroom management problems [22,28,30-32]. From an analysis of posts, Romeu, Guitert, and Sangrà found that $80 \%$ of posts sought student activities [25]. According to a survey of 163 rural teachers in the U.S., $88.1 \%$ indicated that finding curriculum materials was a reason to use an online community [21].

Teachers in specific subject areas sought subject-related resources, advice for curricular issues, or content knowledge. For instance, English Language Arts (ELA) teachers searched for new ideas for reading groups [21]. In an international community of string teachers on Facebook with about 2000 members, the most frequently posted topics were about repertoire, consisting of $16.5 \%$ of the total posts analyzed [32]. In a Facebook group of English teachers in Kenya, 31.8\% of the total posts analyzed related to content knowledge such as English grammar, and 9.8\% were exchanged opinions about curricular issues such as when to introduce a certain topic [33]. In a Facebook group with high school mathematics teachers in Turkey, $85 \%$ of the posts involved math problems and solutions [34]. They also frequently shared math tests and math curricular resources. Content knowledge was also frequently exchanged in a professional learning community of secondary science teachers in the Dominican Republic and rural areas in the U.S. [31].

Technological resources. Teachers also looked for technological resources. Romeu, Guitert, and Sangrà discovered that more than $80 \%$ of posts were related to technological resources [25]. String teachers asked questions about how to use whiteboard and iPads when teaching orchestra and sought recommendations for apps for various devices in their international Facebook group [32]. In a qualitative study of a large Korean teacher community with 100,000 members, participants sought 
digital media to support curriculum including videos to use as supporting materials [30]. Similarly, rural teachers looked for video clips and websites their students would be interested in [21]. It was reported that teachers in subject-specific communities discussed how to effectively integrate technology into their specific subject $[31,34]$.

\subsubsection{Social Network}

Teachers perceived "the capacity for collective reflection and having support from colleagues and opportunities to learn with others" as a benefit of participating in online communities [25]. Teachers sought out colleague teachers or experts about their needs [30,35].

Colleague teachers. Colleague teachers were sought for various reasons. Rural teachers wanted to combat isolation. Many teachers looked for curriculum ideas, teaching expertise, pedagogical practices and collaboration opportunities [21,24,31,34,36-40]. Some teachers leaned on their fellow teachers dealing with school-related or personal issues [34], while others pursued teaching opportunities [33].

Teachers in small schools in rural areas, or those who were the only teacher of the subject, were often isolated in their practice, sometimes had difficulty connecting to other teachers on the same assignments, and accordingly tried to connect with colleague teachers in an online community [21,41]. The survey of rural teachers in the U.S. reported that $58.3 \%$ looked for connection with colleague teachers [21]. The analysis of posts of the Facebook group of 20,000 string teachers revealed that many posts mentioned gratitude for the Facebook group and enthusiasm for finding a community of string teachers [32]. Additionally, the string teachers were highly interested in connecting with qualified teachers by following them upon their retirement or relocation. In interviews with six science teachers who were members of a small community of 11 teachers in New Zealand, all commented that "being isolated with limited opportunities to share ideas" with other teachers with the same specialties was a major reason to participate in the community [38].

Teacher members preferred being able to discuss their problems with other teachers. A member of a large Korean teacher community with 100,000 members mentioned that although they could find teaching resources in other sites, they prefer the community, because they can discuss their problems and collaboratively seek solutions with other teachers [30]. Similarly, teachers in Dominican Republic and rural areas of the U.S. enjoyed sharing authentic and actual solutions that were implemented and worked in their classrooms and having someone to bounce ideas off of in a virtual professional community [31]. In a Facebook group of Turkish high school math teachers, resource requests were made frequently [34]. In the DEN group with diverse members, some interactions helped certain members build their expertise [24]. People looked for these members specifically when they need their particular expertise.

Members used the professional network with fellow educators to find someone with whom to collaborate on projects. A member of DEN commented that "if you're interested in something, then there's usually somebody else ... in the network that is also interested and you can work on it together or you can have your classrooms collaborate together" [24] (p. 111). Collaboration among teachers was commonplace in eTwinning, a very large international community connecting teachers in several European countries [40]. In a study on collaboration between pre-service and in-service teachers, pre-service teachers appreciated insights from in-service teachers' experience to help them understand the current educational environments [27].

Co-construction of knowledge took place after a certain level of participation was established in some communities. In an observation of a small Korean online community of 95 EFL (English as a Foreign Language) teachers, Lim found members became more actively involved in co-creation, co-edition, and co-construction of lesson plans after a strong bond had been established [19]. In a large Korean community, Seo also found that members became motivated to participate in the community after seeking help and being helped by other teachers to return their favor to some other teachers [30]. Likewise, da Cunha Júnior, et al. [42] found that, in their longitudinal case study of a Facebook 
group of 43 teachers, the general low level of participation resulted in no collaboration initiatives among teachers.

In a Facebook group of high school mathematics teachers in Turkey, various school-related and personal issues were shared [34]. Members consulted their peers on "issues related to teachers' obligations, the functioning of the school, appointment procedures and related issues" (p. 605). Personal issues included notice to blood donors for their friend and death notice of a member.

A Facebook community in Kenya had a unique reason for its social network rooted in their culture. Among the total posts analyzed, $4.3 \%$ were sharing or pursuing teaching opportunities [33]. Interestingly, there were teachers who sought to swap their positions in different parts of the nation. According to the authors, "swapping is one of the most convenient and recognized ways that teachers in Kenya use to get transferred to schools of their choice" (p. 139).

Others. Teachers looked for people with different expertise and perspectives. Adrienne introduced some cases where teachers sought people who held different perspectives and expertise [43]. For example, a teacher recruited participants from around the country to discuss topics such as adolescent literacy. Another teacher sent out a request on Twitter to connect his kindergarten pupils to farmers to teach about farms. Technology specialists were sought for consultation on technological use such as software and hardware usage and troubleshooting [35]. The expansion sometimes took place in the opposite way. In a Chinese online community of 200 EFL teachers, where educational consultants were regularly invited, new members tended to prefer to interact with the invited consultants at first. After some involvement in the community, they built peer-to-peer relationships [44].

\subsubsection{Time as a Major Investment}

Time was a major perceived cost, yet a comparative advantage that an online community held over formal professional development activities. In various studies, lack of time was the biggest barrier and cost to the teachers $[7,9,27,30,35,45,46]$. In a survey study of three communities: an international community with 568 members, a national community with 608 members, and a regional community of 112 members in Australia, Duncan-Howell reported that $60 \%$ of the 98 respondents spent less than $3 \mathrm{~h}$ per week in the communities [22]. Brass and Mecoli concluded that insufficient time to participate was one of the reasons of their failed online community of 20 members in Wikispaces, and because of that, the participants expected more to consume information than produce information or collaborate [7]. Similarly, Kamalodeen found most members chose to become a content consumer rather than producer in a mixed methods study of an online community in Spain [46]. A well-designed interface and strong search functions can reduce unnecessary time and effort by facilitating access to desirable information [47].

\subsection{Affective Commitment}

Affective commitment can be induced by providing collegial emotional support to one another. This, in turn, created a sense of belonging and fostered online collaboration. A systematic review of teacher online communities found that one third of the studies reported emotional engagement and support among participants [9].

\subsubsection{Relationship Building and Emotional Support}

Members tried to engage in conversations to build relationships. In the Facebook group of English teachers in Kenya, $27 \%$ of the posts functioned to build relationships, which was the second highest category after content knowledge [33]. Members updated each other about what they were up to and exchanged jokes and encouragement grounded in religious beliefs. Likewise, in the Facebook group of Turkish high school English teachers, members exchanged funny stories and shared some social activities that may be of interest to other members [34].

Members sought emotional support from colleague teachers. In the survey study of three communities of different levels, Duncan-Howell reported that $38 \%$ of the 98 surveyees mentioned 
emotional support as a reason for participation followed by professional requirements [22]. Similarly, Snider found that $11.9 \%$ of rural teachers in a U.S. school district sought emotional support in an online community, and $18.5 \%$ looked for mentoring relationships [21]. His qualitative data revealed that teachers were emotionally exhausted from teaching and needed someone who would understand the uniqueness of what their profession entailed. Especially, teachers in a rural area felt more isolated, because they were the only one in their subject or grade level in their schools. Online communities could connect those in rural areas with colleagues in a similar situation.

Analyses of online posts demonstrate exchanges of emotional experiences and support. In a Facebook group of English teachers in Kenya, 27\% of the posts served to establish bonds among members, which was the second highest after the content knowledge posts [33]. In an analysis of 395 teachers' blog posts and 511 comments, 152 posts described emotional experiences or reactions, 121 comments shared similar experiences related to posts, and 158 comments offered emotional support [48]. Similarly, in another analysis, more than $75 \%$ of the posts were related to sharing experiences and doubts, and almost $80 \%$ of survey respondents considered it important to develop a sense of belonging [25]. It was concluded that sharing student experiences and emotional aspects of the profession fostered affective relationships and a sense of belonging $[25,48]$.

Therefore, members should be encouraged to build relationships among themselves. Additionally, there should be a space where people in similar situations share emotions and communicate their experiences securely, exclusively, and sometimes anonymously, as teachers tend to prefer receiving emotional support from people in their profession [27].

\subsubsection{Extended Interaction}

Sharing emotional aspects has the potential to extend the "spirit of collaboration", which in turn strengthens a sense of belonging. Lim's observation of the small Korean online community of 95 EFL teachers revealed that a sense of community among members led to active sharing and co-construction of knowledge [19]. In the community, the members first focused on building relationships. After a strong bond was established, teaching resources were more actively shared, and knowledge was co-constructed. Similarly, in the large Korean online community of 100,000 members, the most active members provided emotional support among one another, which induced active participation of other members [30]. An interviewee mentioned that "there was a teacher who helped me survive the first year of teaching. I wanted to become like him, like an expert teacher, who not only helps students with learning, but also helps fellow teachers to learn the practices of teaching" [30]. Hodes, Pritz, Kelley, and Foster [18] also witnessed that affective relationships fostered group members' collaboration. In an observation of a small community of 48 members, the group became more cohesive and engaged in activities that involved higher-level, complex thinking, as they shared their emotions and reflection on their practice.

Collaborating on challenging tasks and engaging in meaningful professional conversations helped members create bonds in their relationships. In eTwinning, a very large international community connecting teachers in several European countries, Crawley, Gilleran, Nucci, and Scimeca [40] reflected that members who collaborated on the same challenging task built a sense of belonging and affection not only to the small group, but also to the entire community. During the collaborative process, the members felt connected and experienced warm feelings by knowing that there are teachers who want to make an impact on their students' lives and by getting support from their teacher peers [40]. In a professional learning community of rural science teachers in the U.S. and Dominican Republic, members engaged in professional conversations deeply situated in their specific teaching contexts. This allowed them to share their personal experiences, which helped them develop lasting professional friendships [31]. 


\subsection{Moral Commitment}

Moral commitment is based on one's evaluation of the norms and beliefs of a community against their own [17]. To promote this evaluative process, the coordinators need to explicitly communicate these. Additionally, the core members need to demonstrate the morality. In a systematic review of informal online teacher communities, Macià and Garcia [49] found that participation increased, and interaction evolved, as members set goals, negotiated rules and meanings, and developed trust. Our review suggests that a community can foster moral commitment through publicly sharing professional learning goals and nurturing a healthy community culture.

\subsubsection{Shared Professional Learning Goals}

Articulating goals could be as general as improving teaching or specific as expanding approaches to teaching and learning. For example, the purpose of the Discovery Education Network (DEN) was teacher growth, innovation, and learning in order to improve student achievement [24]. Trust and Horrocks [24] selected a closely aligned purpose of the community with members' interest as one of the six key elements to build an active and thriving community of practice. They emphasized that the shared goal of DEN played a vital role in eliciting member participation and argued that many communities failed "because the purpose of the community did not align with teachers' needs" (p. 112).

Stevenson [39] found that teachers tended to informally collaborate with colleagues who have a similar stance towards implementing the district-mandated curriculum or similar belief in what students need. Luehmann and Tinelli [48] observed a science teacher community where the common interest of the members was implementing a student-centered, inquiry-based approach. They recognized the importance of clearly communicating the goals of their community to attract members who share similar practical theories and personal goals. In their systematic review, Lantz-Andersson, Lundin, and Selwyn [9] found several studies that reported interactions to be conformed to the shared norms and common educational understandings.

The community goals can naturally emerge from its members or be determined by communitybuilders. While it is time-consuming and difficult to facilitate the emergence of professional learning goals in an online community, simply announcing the goals without a proper negotiation process with the members may result in failure to sustain the community. For instance, Brass and Mecoli [7] found that many participants in their Wiki-based community of 20 members saw that the community space was already established by experts, so they expressed discomfort and were reluctant to share their knowledge or experiences through posting, challenging others, or building on other teachers' ideas. The authors viewed these different perspectives on knowledge construction as a major reason for its failure. As such, properly communicating and negotiating the goals are important in achieving shared professional goals.

\subsubsection{Healthy Community Culture}

While shared goals frame what members can collectively pursue, a healthy community culture sets the foundation for such goal-oriented endeavors. Explicitly stated rules or implicitly understood principles can cultivate a healthy community culture [24]. Trust and Horrocks [24] emphasized the importance of setting up guiding principles in DEN, which were explicitly stated to encourage "collaborative learning, teaching, and reciprocity both within and beyond the DEN" (p. 111). Articulating these principles established the positive and supportive culture that encourages members to give back. Reciprocity is "an essential component of healthy communities" [50] (p. 122).

Pursuing diversity and being respectful to different ideas is another characteristic of a healthy community culture. Concluding their systematic review of online communities, Lantz-Andersson, Lundin, and Selwyn [9] warned that members' efforts to conform to the common understanding could lead to a tendency for interaction to be confined to dominant professional discourses. This can make members with new or different ideas reluctant to voice them and discourage meaningful interactions. 
In the community of 200 Chinese EFL teachers, Wu, Gao, and Zhang [44] found that diverse perspectives and opinions coming from heterogeneity of community members were essential for healthy growth of the community. Likewise, Trust and Horrocks [24] reported that the diverse member base of DEN fostered socially distributed learning, in which members can tap into the distributed expertise within the community.

Meaningful participation, such as sharing different ideas or discussing experiments, challenges, and productive failures, took place predominantly in online communities with a high level of trust [8] and a culture where members were open to new ideas and negotiation of the ideas with peers [51]. This culture of mutual respect enabled a heightened sense of belonging, as members felt respected in the community $[9,18,41]$. A healthy culture can contribute to moral and affective commitments by promoting a sense of belonging. After conducting an extensive qualitative study of the community with 284 members, FarNet in New Zealand, Parr and Ward [52] concluded that openness to improvement, trust, and mutual respect were preconditions that enabled the successful development of the community. A study on the community of 200 Chinese EFL teachers also emphasized that members' open-mindedness and mutual respect were crucial in active and meaningful interactions [44]. Therefore, a healthy community culture based on members' open mindedness, mutual respect, and trust should be emphasized to encourage them to embrace different ideas, constructive feedback, and improvement to their practice.

Members appreciated the positive and supportive culture of their online communities. In a self-sustaining, thriving Facebook group of high school mathematics teachers in Turkey, some members reported that they experienced positive and constructive communication that did not exist in their own schools [34]. Similarly in DEN, several interviewees favorably commented about its positive and supportive culture [24]. An interviewee mentioned, "it's real easy to get down and sucked into that negativity [in schools], but when you go to DEN events, the best thing is everybody is so amazingly positive and everybody loves their job ... " (p. 111). The positive and supportive culture can strengthen the bond of members and promote their affective commitment to the community [17].

\subsection{Design Suggestions for Total Commitment}

Our review identified suggestions to design a sustainable online community that induce members' total commitment. First, designers should purposefully create spaces for different types of resources and opportunities for collegial emotional support and collaboration. As the fundamental step in designing an online community, a designer should decide on the number and characteristics of community sub-spaces where different kinds of informational or social communications take place based on the community goals. These spaces can be designated for particular curricular or technological resources, various social networks, emotional support, and collaboration. For example, Indischool, the most active teacher community in Korea with 100,000 members, had four spaces: (1) Indi Community, where members shared their experiences and problems, asked questions, and sought solutions; (2) Indi Library, where teaching resources were stored, shared, and commented on; (3) Indi Club, where members with similar interests or hobbies got together; and (4) Indi Workshop, where members engaged in online professional development workshops held by teacher volunteers [30].

Special interest groups or events can promote collegial support and collaboration by allowing members to closely interact with one another. Macià and García [53] found that a majority of members took a passive role and rarely participated in discussions in the reviewed studies. Wenger et al. [54] proposed several suggestions to foster participation of passive members such as creating small special interest groups or regular events. Trust and Horrocks [24] mentioned that providing various in-person events, ongoing learning opportunities, and encouraging leaders to host social activities fostered a strong sense of community.

In special interest groups, teachers who share a similar interest can work collaboratively on a smaller scale $[41,49,55,56]$. In a case study of 43 teachers in a Facebook group, da Cunha Júnior, van Oers and Kontopodis [42] concluded that teachers tended to more critically collaborate in small groups 
than large groups. To support these groups, members should be able to initiate a collaborative project where they construct a meaningful product that they can actually use and build a closer relationship during collaboration $[41,42,55]$. In eTwinning, there were several features that facilitated collaborative projects [57,58]. Members could search for potential partners using the Search Partners tool by setting specific search criteria such as subject areas, grade levels, geographic regions, or interests. They could easily manage their contacts in the My Contacts section and send messages. They could post in the Partner Finding Forum. Once they found partners, they could create projects, plan, work on and manage them, and report their progress. To support these tasks, eTwinning provided a wiki or blog type tool, file or image sharing, discussion forum, and instant chat function.

Various events can be organized to promote interaction among members such as a series of structured online conversations [8] or offline events to allow for face-to-face interaction [24,56]. Booth [8] reported that both National Education Leaders Network and English Teachers' Online Community used structured online conversations on hand-picked, hot education topics. Members of both found them to be informative. An interviewee commented it to be "a powerful and elevating form of knowledge sharing" (p. 10). The China Education Resources and Services Platform had similar events [44]. A monthly events, members voluntarily chatted online on a topic determined through online voting. Related resources on the topic were posted by administrators, and some star teachers or education experts were invited to the events.

Participation in online communities were often reinforced by face-to-face contact according to a systematic review [53]. In Tapped In, various localized face-to-face events were offered to engage local teachers in discussions on educational topics related to their geographical communities $[59,60]$. These events were announced in monthly newsletters through a mailing list and on a Web calendar [61,62].

Second, designers should provide multiple communication channels to facilitate social, collaborative, and emotional interactions. The communication channels can be categorized by their purpose, mode, or the platform in which the channels are provided to the community members. The purposes can largely be seen as promoting social, emotional, or collaborative interactions among members $[27,42,43]$ or to engage members in efforts to improve the services within their own community by enabling direct communication with the moderators (i.e., participatory design) [5].

Having both synchronous and asynchronous communication tools is crucial, as they support distinctive functions. Selwyn [63] found that members were more willing to exchange personal experiences and more frequently shared ideas and brainstormed topics in synchronous communications than asynchronous ones. Wu, Gao, and Zhang [44] found that synchronous communication increased social and emotional interchange, which helps develop affective commitment. Asynchronous communication was found to be deeply reflective and to engage a wide spectrum of voices that evolved over time $[64,65]$.

Furthermore, these channels can be directly built-in or borrowed from existing tools such as Facebook, Linked In, Google Drive, or Zoom. For example, We Are Teachers integrated their site with social networking site Facebook [66]. If most targeted users are using a particular service, one can build a community within existing social networking services such as Facebook $[29,42,67,68]$ or Twitter $[41,49]$. Snider [21] found that $58.3 \%$ of teachers in a school district used Facebook for connecting with other education professionals. About $80 \%$ of teacher-initiated informally created online communities used existing platforms according to a systematic review of online teacher communities [9].

Third, designers should require members to have a public profile to foster trustworthy relationships while enabling anonymous communication. Community members tend to behave more responsibly when their online activities could affect their reputations $[69,70]$. Furthermore, self-disclosure of identity in online communities was associated with positive social influence, reciprocity, online community trust, and collectivism among members [71]. As such, one can require members to disclose their identity at the beginning of community membership, assign usernames based on actual names [72], let them introduce themselves to the members [56], or set professional information to be publicly accessible such as grade-levels or subject matter specialty $[8,55,73]$. 
However, it should be noted that members may engage in deeper conversation when anonymity is ensured. Robson [74] found that Facebook users with public profiles often felt uncomfortable when critiquing peers' views, and provided only superficial and nice replies during online debates. Lantz-Andersson, Lundin, and Selwyn [9] discovered a lack of critical discussion and reflection in some communities, yet anonymity often led to more critical and challenging interactions. An analysis of 3041 \#Edchat tweets by educators revealed that only three tweets were related to sharing emotions [75]. Similar to the Facebook users, Twitter users might have felt uncomfortable with sharing their emotions with their profiles attached to their tweets.

Fourth, designers should clearly communicate goals and expectations and regulate undesirable activities to nurture a healthy community culture. Clearly communicating goals, values, and regulations of the community and cultivating a healthy culture are the fundamental steps to elicit moral commitment. Although this aspect of online communities has been rarely studied [9], a few studies provided consistent findings on the importance of explicitly stating the community's values and the critical roles that leaders, moderators, and core members play in regulating members' behaviors $[5,8,24]$. The importance of communication of goals and expectations is emphasized in the qualitative study of DEN. Trust and Horrocks [24] selected the presentation of guiding principles of DEN and the purpose of the community as two of the seven essential elements of their thriving community. Their guiding principles were explicitly stated on their website, and the members were encouraged to follow them. Trust and Horrocks [24] suggested collaboratively developing a set of guiding principles with members. Guiding principles can include expectations for participation, norms of the community such as etiquette for communication, privacy, and sharing, and responsibilities of the members and leaders [24]. Trust and Horrocks [24] also recommended co-developing the purpose of the community with members. To do so, community developers or leaders need to identify a purpose that meets teachers' holistic needs, and they also need to revisit the purpose and goals to allow them to evolve with the changing needs and interests of the members [24]. This echoes Kanter's statement that a person's commitment to a social group depends on the extent that the person sees it as closely aligned to his fundamental needs [17].

Fifth, designers should foster leadership that will promote a healthy culture of the community. The critical roles of core members or leaders have been emphasized [8,24]. Core members who assume the roles of leaders or moderators monitored other members' activities, regulated inappropriate behaviors, and promoted desirable ones. Coordination of key members' efforts seemed to encourage teacher collaboration. In a qualitative study of online teacher collaboration, $90 \%$ of the teachers reported that coordination encouraged more meaningful interaction, and $91 \%$ perceived that coordination made interaction more dynamic [25]. Trust and Horrocks [24] also emphasized the critical roles played by various leader roles of DEN. These leaders hosted events, mentored new members, and created content for other members. Trust and Horrocks [24] also asserted that providing members with these leadership opportunities empowered members and ensured that the community of practice continues to thrive. They further recommended "co-designing these roles with the community members and ensuring that the roles represent the needs of the community as well as members' professional interests and goals" (p. 113).

Sixth, establish a feedback system among members and a system between members and moderators. Feedback among members, such as exchanging ratings and comments, promotes knowledge sharing and building. Teachers appreciate critical feedback from peers based on which they can improve their practice $[27,30,42,43]$. For example, in the large Korean community, members appreciated having their lesson design reviewed, revised, and evolved by other teachers [30]. Having a rating system also allows users to search quality resources easily through sorting or filtering.

Another feedback system between members and moderators may play a vital role for maintaining the community, meeting the needs of the users and regulating undesirable behaviors. In Tapped In, a large online community for educators in the U.S., there was the place called Needed Features, where members could request technological features from the moderators [60]. Farooq, Schank, Harris, 
Fusco, and Schlager [5] argued that this participatory design allows the community to improve its services, move forward, and grow. Additionally, members being able to report any undesirable behaviors of other members to the moderators can reduce the burden of monitoring and regulating members' online activities and encourage members to actively participate in shaping a healthy community culture.

Seventh, designers should enhance the usability of the environment to allow efficient participation. A well-designed interface and strong search functions can reduce unnecessary time and effort of members by easily finding and accessing desirable information [47]. Navigation of sub-spaces should be intuitively designed [38], mimicking the natural and representative thinking process of teachers. A strong search function should enable members to be able to find needed information using various variables such as subject areas, grade levels, academic standards or topics, pedagogical approaches, or member ID. Tagging a post by these variables can generate an efficient way for future searching $[58,76]$. Furthermore, a personal storage space can facilitate retrieval of information [58,62].

\section{Concluding Remarks}

This systematic review used a sociological framework developed by Kanter [17] to provide guidelines as to how to design a sustainable community for teachers. According to our review and three other systematic reviews we found on online teacher communities $[9,26,53]$, there was no study that intentionally investigated sustainability of online communities. This is critical addition to the knowledge base of educational researchers, as many resources are invested in creating online communities, and creators of online communities may mistakenly hope that their online spaces will endure. Several failed communities demonstrate that this may be a false assumption, even with the presence of clear goals and accessible ways to participate [e.g., 6,7]. By employing Kanter's framework, this article makes a meaningful contribution to establishing a foundation for this line of research.

Kanter's [17] seminal work and related research suggest that sustaining an online community requires its members' total commitment-instrumentally, affectively, and morally. Additionally, the three types of commitments are mutually reinforced and multiply determined. In other words, affective commitment can promote instrumental and moral commitments. Moral commitment can lead to affective and instrumental commitments. Hence, inducing all types of commitments could make a community strong and active. Thus, attention should be paid to all three types of commitments to sustain a community. However, our review demonstrates imbalanced existing research focused on the three types of commitment as shown in Table A2 More than half of the articles we reviewed were focused on instrumental benefits for professional practice and development. Notably, far fewer than half of the articles were concerned with affective or moral commitment. Those commitments play an essential role in creating a cohesive and socially regulated community that can withstand threats to the existence of the community. Therefore, more research should be conducted with a balanced focus on all three types, especially on the affective and moral commitments.

In practice, one can intentionally design an online community to engage its members in cognitive, cathectic, and evaluative processes to induce such commitment. In particular, we argue that such environments should be designed (1) to maximize benefits (access to quality curricular and technological resources and social network) and minimize costs (time spent searching for the resources needed) to promote members' instrumental commitment; (2) to afford ways to share collegial support and have collaborative experiences that foster further bonding to promote affective commitment; (3) and to clearly communicate the goals of a community while allowing negotiation of them, portray the norms and beliefs of a community, and maintain its healthy community culture to promote moral commitment. This principle can be applied to any online community according to Kanter [17]. This review validates its application to online communities for K-12 educators and adds specificities of the three types of commitments for the population.

This study bears limitations inherent to the nature of literature reviews. Secondary data sources were used, which were reported in available published articles. The articles reviewed may carry the researchers' different focuses stemming from their perspectives and subjectivities, limitations of their 
research methods, and publication bias. Because our analysis results were confined to existing research, we had unbalanced findings in terms of the three types of commitments. In addition, considering that teacher communities may be influenced by culture and other environmental variables, one drawback of this study is that it does not account for cultural considerations. Thus, the results of this study should not be generalized and should be carefully adopted into other contexts.

Three lines of research are recommended for future research directions. First, as Kanter's framework was found to provide unique insights into creating sustainable online communities, it can be used as a conceptual framework to empirically examine existing online communities or to design a new one. This line of research will provide more in-depth insights into the issue and more balanced data about all three types of commitments. Second, our review suggests the availability of fewer research studies conducted on the affective and moral commitments than the instrumental commitment. According to Kanter [17] and related research, those are critical to the sustainability of online communities. Therefore, more research on the affective and moral commitments is recommended. Third, this review was focused on online communities for K-12 educators. Kanter's framework was created based on various types of communities, and it has potential to be applicable to other online communities that support educators in different educational systems or with different roles and even to communities outside education. It is encouraged to use the framework to investigate the sustainability of various other online communities.

Author Contributions: D.L.: conceptualization, original draft preparation, data investigation, and writing and editing. J.J. and S.S.: conceptualization, data investigation, and writing and editing. A.O.-L. and K.G.: review. All authors have read and agreed to the published version of the manuscript.

Funding: This research received no external funding.

Conflicts of Interest: The authors declare no conflict of interest.

\section{Appendix A}

Table A1. List of the Selected Articles for Final Analysis.

\begin{tabular}{|c|c|c|c|}
\hline \# & First Author & Year & Title \\
\hline 1 & Balcikanli & 2015 & $\begin{array}{l}\text { Prospective English language teachers' experiences in } \\
\text { Facebook: Adoption, use and educational use in } \\
\text { Turkish context }\end{array}$ \\
\hline 2 & $\begin{array}{l}\text { Bergviken } \\
\text { Rensfeldt }\end{array}$ & 2018 & $\begin{array}{l}\text { Teachers 'liking' their work? Exploring the realities of teacher } \\
\text { Facebook groups }\end{array}$ \\
\hline 3 & Bett & 2020 & $\begin{array}{l}\text { Can Facebook groups enhance continuing professional } \\
\text { development of teachers? Lessons from Kenya }\end{array}$ \\
\hline 4 & Booth & 2012 & $\begin{array}{l}\text { Cultivating knowledge sharing and trust in online } \\
\text { communities for educators }\end{array}$ \\
\hline 5 & Brass & 2011 & $\begin{array}{l}\text { The (failed) case of the Winston Society Wikispace: Challenges } \\
\text { and opportunities of Web } 2.0 \text { and teacher education }\end{array}$ \\
\hline 6 & Carpenter & 2020 & $\begin{array}{l}\text { Broadening borders to build better schools: Virtual } \\
\text { professional learning communities }\end{array}$ \\
\hline 7 & Carr & 2006 & $\begin{array}{l}\text { Teacher professional learning in an online community: The } \\
\text { experiences of the national quality schooling framework } \\
\text { pilot project }\end{array}$ \\
\hline 8 & Chen & 2011 & Improving teachers' teaching with communication technology \\
\hline 9 & Choi & 2014 & $\begin{array}{l}\text { Learning to get it right: Understanding change processes in } \\
\text { professional development for teachers of English learners }\end{array}$ \\
\hline
\end{tabular}


Table A1. Cont.

\begin{tabular}{|c|c|c|c|}
\hline$\#$ & First Author & Year & Title \\
\hline 10 & Colgan & 1999 & $\begin{array}{l}\text { Transforming professional development: An empirical study } \\
\text { to determine the key aspects of electronic collaboration and } \\
\text { social interaction in the elementary mathematics } \\
\text { teaching community }\end{array}$ \\
\hline 11 & da Cunha Júnior & 2016 & $\begin{array}{l}\text { Collaborating on Facebook: Teachers exchanging experiences } \\
\text { through social networking sites }\end{array}$ \\
\hline 12 & Donnelly & 2013 & $\begin{array}{l}\text { Consuming and creating: Early-adopting science teachers' } \\
\text { perceptions and use of a wiki to support } \\
\text { professional development }\end{array}$ \\
\hline 13 & Duncan-Howell & 2010 & $\begin{array}{l}\text { Teachers making connections: Online communities as a source } \\
\text { of professional learning }\end{array}$ \\
\hline 14 & Farooq & 2007 & $\begin{array}{l}\text { Sustaining a community computing infrastructure for online } \\
\text { teacher professional development: A case study of designing } \\
\text { Tapped In }\end{array}$ \\
\hline 15 & Fusco & 2000 & $\begin{array}{l}\text { Assessing the impact of a large-scale online teacher } \\
\text { professional development community }\end{array}$ \\
\hline 16 & Hodes & 2011 & Developing an online community of in-service teachers \\
\hline 17 & Holmes & 2013 & $\begin{array}{l}\text { School teachers' continuous professional development in an } \\
\text { online learning community: Lessons from a case study of an e } \\
\text { twinning learning event }\end{array}$ \\
\hline 18 & Hur & 2009 & $\begin{array}{l}\text { Teacher participation in online communities: Why do teachers } \\
\text { want to participate in self-generated online communities of } \\
\text { K-12 teachers? }\end{array}$ \\
\hline 19 & Judy Kamalodeen & 2016 & $\begin{array}{l}\text { A mixed methods research approach to exploring teacher } \\
\text { participation in an online social networking website }\end{array}$ \\
\hline 20 & Kampylis & 2012 & $\begin{array}{l}\text { Fostering innovative pedagogical practices through online } \\
\text { networks: The case of eTwinning }\end{array}$ \\
\hline 21 & Lantz-Andersson & 2018 & $\begin{array}{l}\text { Twenty years of online teacher communities: A systematic } \\
\text { review of formally organized and informally developed } \\
\text { professional learning groups }\end{array}$ \\
\hline 22 & Lim & 2017 & $\begin{array}{l}\text { Teachers empowering teachers in an online community of } \\
\text { practice: A case study of Korean EFL teachers' learning to } \\
\text { teach flipped classroom on Naver Band }\end{array}$ \\
\hline 23 & Luehmann & 2008 & $\begin{array}{l}\text { Teacher professional identity development with social } \\
\text { networking technologies: Learning reform through blogging }\end{array}$ \\
\hline 24 & Macià & 2017 & $\begin{array}{l}\text { Properties of teacher networks in Twitter: Are they related to } \\
\text { community-based peer production? }\end{array}$ \\
\hline 25 & Marenzi & 2016 & $\begin{array}{l}\text { Yell/tell: Online community platform for teacher } \\
\text { professional development }\end{array}$ \\
\hline 26 & Palmquist & 2015 & $\begin{array}{l}\text { Participation in the School Orchestra and String Teachers } \\
\text { Facebook v2 group: An online community of practice }\end{array}$ \\
\hline 27 & Parr & 2006 & Building on foundations: Creating an online community \\
\hline 28 & Ranieri & 2012 & $\begin{array}{l}\text { Why (and how) do teachers engage in social networks? An } \\
\text { exploratory study of professional use of Facebook and its } \\
\text { implications for lifelong learning. }\end{array}$ \\
\hline 29 & Rezende da Cunha & 2016 & $\begin{array}{l}\text { Collaborating on Facebook: Teachers exchanging experiences } \\
\text { through social networking sites }\end{array}$ \\
\hline 30 & Robson & 2016 & $\begin{array}{l}\text { Engagement in structured social space: an investigation of } \\
\text { teachers' online peer-to-peer interaction }\end{array}$ \\
\hline
\end{tabular}


Table A1. Cont.

\begin{tabular}{|c|c|c|c|}
\hline$\#$ & First Author & Year & Title \\
\hline 31 & Rolando & 2014 & $\begin{array}{l}\text { Learning with their peers: Using a virtual learning community } \\
\text { to improve an in-service biology teacher education program } \\
\text { in Brazil }\end{array}$ \\
\hline 32 & Romeu & 2016 & $\begin{array}{l}\text { Teacher collaboration network in higher education: Reflective } \\
\text { visions from praxis }\end{array}$ \\
\hline 33 & Schank & 2002 & Painting a landscape onto tapped in 2 \\
\hline 34 & Schlager & 2003 & $\begin{array}{l}\text { Designing equity and diversity into online strategies to } \\
\text { support new teachers }\end{array}$ \\
\hline 35 & Selwyn & 2000 & $\begin{array}{l}\text { Creating a "connected" community? Teachers' use of an } \\
\text { electronic discussion group }\end{array}$ \\
\hline 36 & Seo & 2013 & $\begin{array}{l}\text { Professional learning of observers, collaborators, and } \\
\text { contributors in a teacher-created online community in Korea }\end{array}$ \\
\hline 37 & Snider & 2009 & $\begin{array}{l}\text { A critical analysis of rural teachers' usage of } \\
\text { online communities }\end{array}$ \\
\hline 38 & Trust & 2019 & $\begin{array}{l}\text { Six key elements identified in an active and thriving blended } \\
\text { community of practice }\end{array}$ \\
\hline 39 & Tsai & 2011 & $\begin{array}{l}\text { Levels and patterns of participation and social interaction in } \\
\text { an online learning community for learning to teach }\end{array}$ \\
\hline 40 & Vuorikari & 2011 & $\begin{array}{l}\text { ICT-based school collaboration, teachers' networks and their } \\
\text { opportunities for teachers' professional development-a case } \\
\text { study on eTwinning }\end{array}$ \\
\hline 41 & Wesely & 2013 & $\begin{array}{l}\text { Investigating the community of practice of world language } \\
\text { educators on Twitter }\end{array}$ \\
\hline 42 & $\mathrm{Wu}$ & 2014 & $\begin{array}{l}\text { Chinese EFL teachers' social interaction and socio-cognitive } \\
\text { presence in synchronous computer-mediated communication }\end{array}$ \\
\hline 43 & Yildirim & 2019 & $\begin{array}{l}\text { Using Facebook groups to support teachers' } \\
\text { professional development }\end{array}$ \\
\hline
\end{tabular}

\section{Appendix B}

Table A2. Analysis Results of Selected Articles.

\begin{tabular}{ccccc}
\hline First Author (year) & $\begin{array}{c}\text { Instrumental } \\
\text { Commitment }\end{array}$ & $\begin{array}{c}\text { Affective } \\
\text { Commitment }\end{array}$ & $\begin{array}{c}\text { Moral } \\
\text { Commitment }\end{array}$ & $\begin{array}{c}\text { Design } \\
\text { Suggestions }\end{array}$ \\
\hline Balcikanli (2015) & $\mathrm{X}$ & & & $\mathrm{X}$ \\
\hline Bergviken Rensfeldt (2018) & & $\mathrm{X}$ & $\mathrm{X}$ \\
\hline Bett (2020) & $\mathrm{X}$ & & $\mathrm{X}$ & \\
\hline Booth (2012) & & & \\
\hline Brass (2011) & $\mathrm{X}$ & $\mathrm{X}$ & $\mathrm{X}$ \\
\hline Carpenter (2020) & $\mathrm{X}$ & & \\
\hline Carr (2006) & $\mathrm{X}$ & & \\
\hline Chen (2011) & $\mathrm{X}$ & & $\mathrm{X}$ \\
\hline Choi (2014) & $\mathrm{X}$ & & \\
\hline Colgan (1999) & & & \\
\hline da Cunha Júnior (2016) & & & \\
\hline
\end{tabular}


Table A2. Cont.

\begin{tabular}{|c|c|c|c|c|}
\hline First Author (year) & $\begin{array}{l}\text { Instrumental } \\
\text { Commitment }\end{array}$ & $\begin{array}{c}\text { Affective } \\
\text { Commitment }\end{array}$ & $\begin{array}{c}\text { Moral } \\
\text { Commitment }\end{array}$ & $\begin{array}{c}\text { Design } \\
\text { Suggestions }\end{array}$ \\
\hline Donnelly (2013) & $x$ & & & $x$ \\
\hline Duncan-Howell (2010) & $X$ & $x$ & & \\
\hline Farooq (2007) & & & & $x$ \\
\hline Fusco (2000) & $X$ & & & \\
\hline Hodes (2011) & & $x$ & & \\
\hline Holmes (2013) & & & & $x$ \\
\hline Hur (2009) & $x$ & & & \\
\hline Judy Kamalodeen (2016) & $x$ & & & \\
\hline Kampylis (2012) & & & & $x$ \\
\hline Lantz-Andersson (2018) & $X$ & $x$ & $x$ & $x$ \\
\hline $\operatorname{Lim}(2017)$ & $x$ & $x$ & & \\
\hline Luehmann (2008) & & $x$ & $x$ & \\
\hline Macià (2017) & & & & $x$ \\
\hline Marenzi (2016) & & & & $x$ \\
\hline Palmquist (2015) & $x$ & & & \\
\hline Parr (2006) & $x$ & & $x$ & \\
\hline Ranieri (2012) & & & & $x$ \\
\hline Rezende da Cunha (2016) & $x$ & & & $x$ \\
\hline Robson (2016) & & & & $x$ \\
\hline Rolando (2014) & $x$ & & & \\
\hline Romeu (2016) & $x$ & $x$ & & $x$ \\
\hline Schank (2002) & & & & $x$ \\
\hline Schlager (2003) & & & & $x$ \\
\hline Selwyn (2000) & & & & $x$ \\
\hline Seo (2013) & $x$ & $x$ & & $x$ \\
\hline Snider (2009) & $X$ & $x$ & & \\
\hline Trust (2019) & $x$ & $x$ & $x$ & $x$ \\
\hline Tsai (2011) & $x$ & $x$ & & \\
\hline Vuorikari (2011) & & & & $x$ \\
\hline Wesely (2013) & $x$ & & $x$ & \\
\hline $\mathrm{Wu}(2014)$ & $X$ & & $x$ & $x$ \\
\hline Yildirim (2019) & $x$ & $x$ & $x$ & \\
\hline Total & 26 & 13 & 9 & 23 \\
\hline$\%$ & $67 \%$ & $33 \%$ & $23 \%$ & $59 \%$ \\
\hline
\end{tabular}




\section{Appendix C}

Table A3. Selected Articles for Final Analysis: Community Information.

\begin{tabular}{|c|c|c|c|c|c|c|}
\hline First Author (year) & Name & Size & Country & Subject Area & Membership & Network Used \\
\hline $\begin{array}{l}\text { Balcikanli } \\
\quad(2015)\end{array}$ & $\begin{array}{c}\text { PELTs } \\
\text { (Prospective English Language } \\
\text { Teachers) } \\
\end{array}$ & Not reported & Turkey & EFL & By invitation & Facebook \\
\hline $\begin{array}{l}\text { Bergviken Rensfeldt } \\
\text { (2018) }\end{array}$ & Flip-it & 13,000 & Sweden & Technology-based pedagogy & $\begin{array}{l}\text { Initially established as an } \\
\text { open group, later } \\
\text { reconfigured as closed }\end{array}$ & Facebook \\
\hline $\begin{array}{c}\text { Bett } \\
(2020)\end{array}$ & Teachers of English (ToE) & 20,592 & Africa & English & Not reported & Facebook \\
\hline $\begin{array}{l}\text { Booth } \\
(2012)\end{array}$ & $\begin{array}{l}\text { Case 1. National Education } \\
\text { Leaders Network } \\
\text { Case 2. English Teachers' Online } \\
\text { Community }\end{array}$ & $\begin{array}{c}\# 1: 300 \\
\# 2: 20,000\end{array}$ & U.S. & $\begin{array}{c}\text { \#1: All } \\
\text { \#2: English }\end{array}$ & $\begin{array}{c}\text { \#1.By invitation } \\
\text { \#2. Open }\end{array}$ & Not reported \\
\hline $\begin{array}{l}\text { Brass } \\
(2011)\end{array}$ & Winston Society & 20 & U.S. & English & By invitation & Wiki \\
\hline $\begin{array}{c}\text { Carpenter } \\
(2020)\end{array}$ & Not reported & $\mathrm{N} / \mathrm{A}$ & $\begin{array}{c}\text { U.S. (Texas), } \\
\text { Dominican Republic }\end{array}$ & N/A & $\mathrm{N} / \mathrm{A}$ & N/A \\
\hline $\begin{array}{l}\text { Carr } \\
(2006)\end{array}$ & $\begin{array}{c}\text { NQSF } \\
\text { (National Quality Schooling } \\
\text { Framework Pilot Project) }\end{array}$ & 100 & Australia & All & By invitation & Not reported \\
\hline $\begin{array}{l}\text { Chen } \\
(2011)\end{array}$ & Not reported & 26 & U.S. & All & By invitation & Wikispaces \\
\hline $\begin{array}{l}\text { Choi } \\
(2014)\end{array}$ & Blackboard & 120 & U.S. & English Learners [ELs] & By invitation & Not reported \\
\hline $\begin{array}{c}\text { Colgan } \\
(1999)\end{array}$ & Connect-Me & 60 & International & Math & Not reported & Not reported \\
\hline $\begin{array}{c}\text { da Cunha Júnior } \\
\text { (2016) }\end{array}$ & $\begin{array}{c}\text { TFC } \\
\text { (Teachers who use Facebook in } \\
\text { Classrooms) }\end{array}$ & 43 & Brazil & All & By invitation & Facebook \\
\hline $\begin{array}{l}\text { Donnelly } \\
\text { (2013) }\end{array}$ & Not reported & 11 & New Zealand & Science & By invitation & Wikispaces \\
\hline $\begin{array}{c}\text { Duncan-Howell } \\
\text { (2010) }\end{array}$ & $\begin{array}{l}\text { Case 1. BECTA top teachers } \\
\text { Case 2. Oz-TeacherNet } \\
\text { Case 3. SSABSA English Teachers }\end{array}$ & $\begin{array}{l}\# 1: 568 \\
\# 2: 608 \\
\# 3: 112\end{array}$ & $\begin{array}{l}\text { \#1: International } \\
\text { \#2: Australian } \\
\text { national } \\
\text { \#3: Australian state }\end{array}$ & $\begin{array}{l}\text { \#1: All } \\
\text { \#2: All } \\
\text { \#3: English }\end{array}$ & Not reported & Not reported \\
\hline
\end{tabular}


Table A3. Cont.

\begin{tabular}{|c|c|c|c|c|c|c|}
\hline First Author (year) & Name & Size & Country & Subject Area & Membership & Network Used \\
\hline $\begin{array}{l}\text { Farooq } \\
(2007)\end{array}$ & Tapped In & 20,000 & U.S. & All & Not reported & Not reported \\
\hline $\begin{array}{l}\text { Fusco } \\
(2000)\end{array}$ & Tapped In & 6000 & U.S. & All & Open & Not reported \\
\hline $\begin{array}{l}\text { Hodes } \\
(2011)\end{array}$ & Not reported & 48 & U.S. & All & By invitation & Not reported \\
\hline $\begin{array}{c}\text { Holmes } \\
(2013)\end{array}$ & eTwinning & Not reported & International (EU) & All & Not reported & $\begin{array}{l}\text { Specifically designed } \\
\text { platform }\end{array}$ \\
\hline $\begin{array}{l}\text { Hur } \\
(2009)\end{array}$ & $\begin{array}{l}\text { Case 1: Teacher Focus community } \\
\text { Case 2: WeTheTeachers } \\
\text { community } \\
\text { Case 3: The Teaching community } \\
\text { in LiveJournal (T-LJ) }\end{array}$ & $\begin{array}{l}\text { Case 1: } 5300 \\
\text { Case 2: } 2500 \\
\text { Case 3: } 1500\end{array}$ & International & All & Not reported & Not reported \\
\hline $\begin{array}{l}\text { Judy Kamalodeen } \\
\text { (2016) }\end{array}$ & Not reported & Not reported & Spain & All & By invitation & Not reported \\
\hline $\begin{array}{l}\text { Kampylis } \\
\text { (2012) }\end{array}$ & eTwinning & Not reported & International (EU) & All & Not reported & Not reported \\
\hline $\begin{array}{l}\text { Lantz-Andersson } \\
\text { (2018) }\end{array}$ & $\mathrm{N} / \mathrm{A}$ & N/A & N/A & N/A & $\mathrm{N} / \mathrm{A}$ & Not reported \\
\hline $\begin{array}{l}\text { Luehmann } \\
\text { (2008) }\end{array}$ & $\begin{array}{l}\text { Implementing Curricular Reform } \\
\text { in Science Education }\end{array}$ & Not reported & U.S. & Science Education & Not reported & Not reported \\
\hline $\begin{array}{l}\text { Macià } \\
\text { (2017) }\end{array}$ & N/A & N/A & N/A & N/A & N/A & Not reported \\
\hline $\begin{array}{c}\text { Marenzi } \\
(2016)\end{array}$ & $\begin{array}{l}\text { Young/Teen English Language } \\
\text { Learners (YELL/TELL) }\end{array}$ & Not reported & Italy & EFL & Not reported & Not reported \\
\hline $\begin{array}{l}\text { Palmquist } \\
\text { (2015) }\end{array}$ & SOST v2 Facebook group & 2000 & International & Orchestra and String teachers & Open & Facebook \\
\hline $\begin{array}{c}\text { Parr } \\
(2006)\end{array}$ & FarNet & 284 & New Zealand & All & By invitation & Not reported \\
\hline
\end{tabular}


Table A3. Cont.

\begin{tabular}{|c|c|c|c|c|c|c|}
\hline First Author (year) & Name & Size & Country & Subject Area & Membership & Network Used \\
\hline $\begin{array}{l}\text { Ranieri } \\
(2012)\end{array}$ & Five Facebook group pages & $\begin{array}{c}\text { Group 1: } 1532 \\
\text { Group 2: } 698 \\
\text { Group 3: } 746 \\
\text { Group 4: } 1078 \\
\text { Group 5: } 1510\end{array}$ & Italy & $\begin{array}{c}\text { \#1,2,3: All } \\
\text { \#4: Learning support } \\
\text { \#5: Learning disabilities }\end{array}$ & $\begin{array}{c}\text { 1. Approved by an } \\
\text { administrator or invited } \\
\text { by another member } \\
2 \text {. Open } \\
3 \text {. Open } \\
4 \text {. Approved by an } \\
\text { administrator or invited } \\
\text { by another member } \\
5 \text {. Approved by an } \\
\text { administrator or invited } \\
\text { by another member }\end{array}$ & Facebook \\
\hline $\begin{array}{l}\text { Rezende da Cunha } \\
\text { (2016) }\end{array}$ & $\begin{array}{c}\text { TFC } \\
\text { (Teachers who use Facebook in } \\
\text { Classrooms) }\end{array}$ & 43 & Brazil & Not reported & By Invitation & Facebook \\
\hline $\begin{array}{l}\text { Robson } \\
(2016)\end{array}$ & Not reported & $\begin{array}{c}\text { Forum: } 363 \\
\text { Facebook Page: } 334 \\
\text { Facebook Group: } 563\end{array}$ & U.K. & Religious Education & Not reported & Facebook \\
\hline $\begin{array}{l}\text { Rolando } \\
(2014)\end{array}$ & $\begin{array}{c}\text { VLC-Bio } \\
\text { (Biology teachers network of the } \\
\text { State of Rio de Janeiro) }\end{array}$ & 454 & Brazil & Biology & Not reported & $\begin{array}{c}\text { Ning Network } \\
\text { (http://biologiacecierj } \\
\text { ning.com/) }\end{array}$ \\
\hline $\begin{array}{l}\text { Romeu } \\
\text { (2016) }\end{array}$ & Not reported & Not reported & Not reported & Not reported & Not reported & Not reported \\
\hline $\begin{array}{c}\text { Schank } \\
(2002)\end{array}$ & Tapped In & Not reported & U.S. & All & Not reported & Not reported \\
\hline $\begin{array}{l}\text { Schlager } \\
(2003)\end{array}$ & $\begin{array}{l}\text { MPS (Milwaukee Public Schools) } \\
\text { Professional Support Community }\end{array}$ & Not reported & U.S. & All & Not reported & $\begin{array}{l}\text { Specifically designed } \\
\text { platform }\end{array}$ \\
\hline $\begin{array}{c}\text { Selwyn } \\
(2000)\end{array}$ & SENCo forum & 1347 & U.K. & Special Education & Not reported & Not reported \\
\hline $\begin{array}{c}\text { Seo } \\
(2013)\end{array}$ & Indischool & 100,000 & S.Korea & All & Open & Not reported \\
\hline $\begin{array}{l}\text { Snider } \\
(2009)\end{array}$ & $\mathrm{N} / \mathrm{A}$ & N/A & U.S. & All & $\mathrm{N} / \mathrm{A}$ & Not reported \\
\hline $\begin{array}{c}\text { Trust } \\
(2019)\end{array}$ & $\begin{array}{l}\text { Discovery Educator Network } \\
\text { (DEN) }\end{array}$ & Not reported & U.S. & $\begin{array}{c}\text { K-12 teachers, staff, school } \\
\text { leaders }\end{array}$ & Not reported & Not reported \\
\hline $\begin{array}{l}\text { Tsai } \\
(2011)\end{array}$ & $\begin{array}{l}\text { NETwork (Nurturing Elementary } \\
\text { Teachers' work) }\end{array}$ & 92 & Not reported & Science & Closed & Sakai 2.0 \\
\hline $\begin{array}{l}\text { Vuorikari } \\
(2011)\end{array}$ & eTwinning & 76,551 & International & All & Open & $\begin{array}{l}\text { Specifically designed } \\
\text { platform }\end{array}$ \\
\hline
\end{tabular}


Table A3. Cont.

\begin{tabular}{|c|c|c|c|c|c|c|}
\hline First Author (year) & Name & Size & Country & Subject Area & Membership & Network Used \\
\hline $\begin{array}{l}\text { Wesely } \\
(2013)\end{array}$ & Not reported & 500 & U.S. & World Languages & Open & Twitter \\
\hline $\begin{array}{c}\text { Wu } \\
(2014)\end{array}$ & $\begin{array}{l}\text { English Teaching Forum of the } \\
\text { China Education Resources and } \\
\text { Services Platform }\end{array}$ & 200 & China & All & Not reported & Not reported \\
\hline $\begin{array}{l}\text { Yildirim } \\
\text { (2019) }\end{array}$ & $\begin{array}{c}\text { Chamber of Ministry of National } \\
\text { Education High School } \\
\text { Mathematics Teachers }\end{array}$ & 13,000 & Turkey & Mathematics & $\begin{array}{l}\text { Closed (Approved by the } \\
\text { administrators) }\end{array}$ & Facebook \\
\hline
\end{tabular}




\section{References}

1. Wenger, E. Communities of practice: Learning as a social system. Syst. Think. 1998, 9, 2-3. Available online: https://thesystemsthinker.com/communities-of-practice-learning-as-a-social-system/ (accessed on 7 May 2020). [CrossRef]

2. Carr, N.; Chambers, D.P. Teacher professional learning in an online community: The experiences of the national quality schooling framework pilot project. Technol. Pedagog. Educ. 2006, 15, 143-157. [CrossRef]

3. Gutierrez, C.; Bryan, C. Online community becomes a pathway to teacher leadership. J. Staff Dev. 2010, 31, 42-47.

4. OECD. TALIS 2013 Results: An International Perspective on Teaching and Learning; OECD Publishing: Paris, France, 2014.

5. Farooq, U.; Schank, P.; Harris, A.; Fusco, J.; Schlager, M.S. Sustaining a community computing infrastructure for online teacher professional development: A case study of designing Tapped In. Comput. Supported. Coop. Work 2007, 16, 397-429. [CrossRef]

6. McPherson, M.; Nunes, M.B. The failure of a virtual social space (VSS) designed to create a learning community: Lessons learned. Br. J. Educ. Technol. 2004, 35, 305-321. [CrossRef]

7. Brass, J.; Mecoli, S. The (failed) case of the Winston Society Wikispace: Challenges and opportunities of Web 2.0 and teacher education. Contemp. Issues Technol. Teach. Educ. 2011, 11, 149-166.

8. Booth, S.E. Cultivating Knowledge Sharing and Trust in Online Communities for Educators. J. Educ. Comput. Res. 2012, 47, 1-31. [CrossRef]

9. Lantz-Andersson, A.; Lundin, M.; Selwyn, N. Twenty years of online teacher communities: A systematic review of formally-organized and informally-developed professional learning groups. Teach. Teach. Educ. 2018, 75, 302-315. [CrossRef]

10. Vygotsky, L.S. Mind in Society: The Development of Higher Psychological Processes; Harvard University Press: Cambridge, MA, USA, 1978.

11. Glaser, B.G.; Strauss, A.L.; Strutzel, E. The discovery of grounded theory: Strategies for qualitative research. Nurs. Res. 1968, 17, 364. [CrossRef]

12. Kanter, R.M. Commitment and the internal organization of millennial movements. Am. Behav. Sci. 1972, 16, 219-243. [CrossRef]

13. Allen, N.J.; Meyer, J.P. The measurement and antecedents of affective, continuance and normative commitment to the organization. J. Occup. Psychol. 1990, 63, 1-18. [CrossRef]

14. Bryson, J.M. Strategic Planning for Public and Nonprofit Organizations: A Guide to Strengthening and Sustaining Organizational Achievement; John Wiley \& Sons: Hoboken, NJ, USA, 2011; Volume 1.

15. Gundlach, G.T.; Achrol, R.S.; Mentzer, J.T. The Structure of Commitment in Exchange. J. Mark. 1995, 59, 78-92. [CrossRef]

16. Gilliland, D.I.; Bello, D.C. Two sides to attitudinal commitment: The effect of calculative and loyalty commitment on enforcement mechanisms in distribution channels. J. Acad. Mark. Sci. 2002, 30, 24-43. [CrossRef]

17. Kanter, R.M. Commitment and Community: Communes and Utopias in Sociological Perspective; Harvard University Press: Cambridge, MA, USA, 1972.

18. Hodes, C.; Pritz, S.; Kelley, P.; Foster, J. Developing an online community of inservice teachers. Contemp. Issues Technol. Teach. Educ. 2011, 11,313-323.

19. Lim, S.H. Teachers empowering teachers in an online community of practice: A case study of Korean EFL teachers' learning to teach flipped classroom on Naver Band. Multimed. Assist. Lang. Learn. 2017, 20, $109-143$. [CrossRef]

20. Chen, L. Improving teachers' teaching with communication technology. J. Educ. Technol. Syst. 2011, 40, 35-43. [CrossRef]

21. Snider, S.A. A Critical Analysis of Rural Teachers' Usage of Online Communities. Ph.D. Thesis, Southern Illinois University at Carbondale, Carbondale, IL, USA, 2009.

22. Duncan-Howell, J. Teachers making connections: Online communities as a source of professional learning. Br. J. Educ. Technol. 2010, 41, 324-340. [CrossRef]

23. Smith, M. Voice from the WELL: The Logic of the Virtual Commons; Department of Sociology, University of California: Los Angeles, CA, USA, 1992. 
24. Trust, T.; Horrocks, B. Six key elements identified in an active and thriving blended Community of Practice. TechTrends 2019, 63, 108-115. [CrossRef]

25. Romeu, T.; Guitert, M.; Sangrà, A. Teacher collaboration network in higher education: Reflective visions from praxis. Innov. Educ. Teach. Int. 2016, 53, 592-604. [CrossRef]

26. Vescio, V.; Ross, D.; Adams, A. A review of research on the impact of professional learning communities on teaching practice and student learning. Teach. Teach. Educ. 2008, 24, 80-91. [CrossRef]

27. Tsai, I.C. Levels and patterns of participation and social interaction in an online learning community for learning to teach. J. Interact. Learn. Res. 2011, 22, 191-239.

28. Colgan, L.; Higginson, W.; Sinclair, N. Transforming professional development: An empirical study to determine the key aspects of electronic collaboration and social interaction in the elementary mathematics teaching community. Alta. J. Educ. Res. 1999, 45, 315-319.

29. Balcikanli, C. Prospective English language teachers' experiences in Facebook: Adoption, use and educational use in Turkish context. Int. J. Educ. Dev. Using Inf. Commun. Technol. 2015, 11, 82-99.

30. Seo, K. Professional Learning of observers, collaborators, and contributors in a teacher-created online community in Korea. Asia Pac. J. Educ. 2014, 34, 337-350. [CrossRef]

31. Carpenter, D.; Munshower, P. Broadening borders to build better schools: Virtual professional learning communities. Int. J. Educ. Manag. 2019, 34, 296-314. [CrossRef]

32. Palmquist, J.E.; Barnes, G.V. Participation in the school orchestra and string teachers Facebook v2 group: An online community of practice. Int. J. Community Music. 2015, 8, 93-103. [CrossRef]

33. Bett, H.; Makewa, L. Can Facebook groups enhance continuing professional development of teachers? Lessons from Kenya. Asia Pac. J. Teach. Educ. 2020, 48, 132-146. [CrossRef]

34. Yildirim, I. Using Facebook groups to support teachers' professional development. Technol. Pedagog. Educ. 2019, 1-21. [CrossRef]

35. Stevenson, H.J. Teachers' informal collaboration regarding technology. J. Res. Technol. Educ. 2004, 37, 129-144. [CrossRef]

36. Rolando, L.G.R.; Salvador, D.F.; Souza, A.H.S.; Luz, M.R.M.P. Learning with their peers: Using a virtual learning community to improve an in-service biology teacher education program in Brazil. Teach. Teach. Educ. 2014, 44, 44-55. [CrossRef]

37. Hur, J.; Brush, T.A. Teacher participation in online communities: Why do teachers want to participate in self-generated online communities of K-12 teachers? J. Res. Technol. Educ. 2009, 41, 279-303. [CrossRef]

38. Donnelly, D.F.; Boniface, S. Consuming and creating: Early-adopting science teachers' perceptions and use of a wiki to support professional development. Comput. Educ. 2013, 68, 9-20. [CrossRef]

39. Stevenson, H.J. To adapt or subscribe: Teachers' informal collaboration and view of mandated curricula. Issues Teach. Educ. 2008, 17, 75-95.

40. Crawley, C.; Gilleran, A.; Nucci, D.; Scimeca, S. Voices of Etwinning-Teachers Talk; Central Support Service for Etwinning \& European Schoolnet: Brussels, Belgium, 2013.

41. Wesely, P.M. Investigating the community of practice of world language educators on twitter. J. Teach. Educ. 2013, 64, 305-318. [CrossRef]

42. da Cunha Júnior, F.; van Oers, B.; Kontopodis, M. Collaborating on Facebook: Teachers exchanging experiences through social networking sites. Cult. Hist. Psychol. 2016, 12, 290-309. [CrossRef]

43. Adrienne, L. Twitter evolving into professional-development tool. Educ. Week 2011, 30, 20. Available online: https://www.edweek.org/ew/articles/2011/07/13/36twitter.h30.html (accessed on 17 June 2019).

44. Wu, H.; Gao, J.; Zhang, W. Chinese EFL teachers: Social interaction and socio-cognitive presence in synchronous computer-mediated communication. Lang. Learn. Technol. 2014, 18, 228-254.

45. Fusco, J.; Gehlbach, H.; Schlager, M.S. Assessing the Impact of a Large-Scale Online Teacher Professional Development Community. In Proceedings of the 11th International Conference for the Society for Information Technology and Teacher Education, Association for the Advancement of Computing in Education (AACE), Waynesville, NC, USA, 5-10 March 2000; pp. 2178-2183. Available online: https:/tappedin.org/publications/ 2000/AssessingComm.pdf (accessed on 22 November 2020).

46. Judy Kamalodeen, V.; Jameson-Charles, M. A mixed methods research approach to exploring teacher participation in an online social networking website. Int. J. Qual. Methods 2016, 15, 1-14. [CrossRef]

47. Yeh, Y. Integrating collaborative PBL with blended learning to explore preservice teachers' development of online learning communities. Teach. Teach. Educ. Int. J. Res. Stud. 2010, 26, 1630-1640. [CrossRef] 
48. Luehmann, A.L.; Tinelli, L. Teacher professional identity development with social networking technologies: Learning reform through blogging. Educ. Media Int. 2008, 45, 323-333. [CrossRef]

49. Macià, M.; Garcia, L. Properties of teacher networks in Twitter: Are they related to community-based peer production? Int. Rev. Res. Open Distrib. Learn. 2017, 18, 110-140. [CrossRef]

50. Jones, A.; Preece, J. Online communities for teachers and lifelong learners: A framework for comparing similarities and identifying differences in communities of practice and communities of interest. Int. J. Learn. Technol. 2006, 2, 112-137. [CrossRef]

51. Chih-Hsiung, T.; Corry, M. Building Active Online Interaction via a Collaborative Learning Community. Comput. Sch. 2003, 20, 51-59.

52. Parr, J.; Ward, L. Building on foundations: Creating an online community. J. Technol. Teach. Educ. 2006, 14, 775-793.

53. Macià, M.; García, I. Informal online communities and networks as a source of teacher professional development: A review. Teach. Teach. Educ. 2016, 55, 291-307. [CrossRef]

54. Wenger, E.; McDermott, R.A.; Snyder, W. Cultivating Communities of Practice: A Guide to Managing Knowledge; Harvard Business Press: Boston, MA, USA, 2002.

55. Holmes, B. School teachers' continuous professional development in an online learning community: Lessons from a case study of an e twinning learning event. Eur. J. Educ. 2013, 48, 97-112. [CrossRef]

56. Schlager, M.S.; Fusco, J.; Koch, M.; Crawford, V.; Phillips, M. Designing Equity and Diversity into Online Strategies to Support New Teachers. In Proceedings of the National Educational Computing Conference (NECC), Seattle, WA, USA, 1 July 2003.

57. Vuorikari, R.; Berlanga, A.; Cachia, R.; Cao, Y.; Fetter, S.; Gilleran, A.; Klamma, R.; Punie, Y.; Scimeca, S.; Sloep, P.; et al. ICT-Based School Collaboration, Teachers' Networks and their Opportunities for Teachers' Professional Development-A Case Study on Etwinning. In Advances in Web-Based Learning-ICWL 2011; Leung, H., Popescu, E., Cao, Y., Lau, R.H., Nejdl, W., Eds.; Springer: Berlin/Heidelberg, Germany, 2011; Volume 7048, pp. 112-121.

58. Kampylis, P.; Bocconi, S.; Punie, Y. Fostering Innovative Pedagogical Practices through Online Networks: The Case of Etwinning. In Proceedings of the SQM/INSPIRE 2012 Conference, Tampere, Finland, 21-23 August 2012.

59. Schlager, M.S.; Fusco, J. Teacher professional development, technology, and communities of practice: Are we putting the cart before the horse? Inf. Soc. 2003, 19, 203-220. [CrossRef]

60. Tapped In. Available online: http://www.tappedin.org/ (accessed on 7 May 2020).

61. Schank, P.K.; Harris, Z.; Schlager, M.S. Painting a Landscape onto Tapped In 2. In Proceedings of the CSCW Workshop on the Role of Place in Virtual Communities, Seattle, WA, USA, 16-20 November 2002; Available online: https://www.tappedin.org/publications/2002/TI2PlaceCSCW.pdf (accessed on 7 May 2020).

62. Schlager, M.S.; Fusco, J.; Schank, P.K. Cornerstones for an on-line community of education professionals. Technol. Soc. Mag. IEEE 1998, 17, 15-21. [CrossRef]

63. Selwyn, N. Creating a "connected" community? Teachers' use of an electronic discussion group. Teach. Coll. Rec. 2000, 102, 750 .

64. Andrew, N.; Ferguson, D.; Wilkie, G.; Corcoran, T.; Simpson, L. Developing professional identity in nursing academics: The role of communities of practice. Nurse Educ. Today 2009, 29, 607-611. [CrossRef]

65. Choi, D.S.-Y.; Morrison, P. Learning to get it right: Understanding change processes in professional development for teachers of English learners. Prof. Dev. Educ. 2014, 40, 416-435. [CrossRef]

66. Simba Information. Teacher learning communities expanding. Electron. Educ. Rep. 2008, 15, 1-3.

67. Bergviken Rensfeldt, A.; Hillman, T.; Selwyn, N. Teachers 'liking' their work? Exploring the realities of teacher Facebook groups. Br. Educ. Res. J. 2018, 44, 230-250. [CrossRef]

68. Ranieri, M.; Manca, S.; Fini, A. Why (and how) do teachers engage in social networks? An exploratory study of professional use of Facebook and its implications for lifelong learning. Br. J. Educ. Technol. 2012, 43, 754-769. [CrossRef]

69. Grohol, J. Anonymity and Online Community: Identity Matters. In Community, Usability; 2006; Volume 214, Available online: https://alistapart.com/article/identitymatters/ (accessed on 17 June 2019).

70. Kollock, P.; Smith, M. Managing the virtual commons: Cooperation and Conflict in Computer Communities. In Computer-Mediated Communication: Linguistic, Social, and Cross-Cultural Perspectives; Herring, S.C., Ed.; John Benjamins Publishing: Amsterdam, The Netherlands, 1996; pp. 109-128. 
71. Posey, C.; Lowry, P.B.; Roberts, T.L.; Ellis, T.S. Proposing the online community self-disclosure model: The case of working professionals in France and the U.K. who use online communities. Eur. J. Inf. Syst. 2010, 19, 181-195. [CrossRef]

72. Schlager, M.S.; Schank, P.K. Tapped In: A New On-Line Teacher Community Concept for the Next Generation of Internet Technology. In Proceedings of the 2nd International Conference on Computer Support for Collaborative Learning, Toronto, ON, Canada, 10-14 December 1997; pp. 234-243. Available online: https://www.tappedin.org/publications/1997/NextGenCSCL.pdf (accessed on 22 November 2020).

73. Allen, E.I.; Seaman, J. Digital Learning Compass: Distance Education Enrollment Report 2017; Babson Survey Research Group: Wellesley, MA, USA, 2017.

74. Robson, J. Engagement in structured social space: An investigation of teachers' online peer-to-peer interaction. Learn. Media Technol. 2016, 41, 119-139. [CrossRef]

75. Staudt Willet, K.B. Revisiting how and why educators use Twitter: Tweet types and purposes in \#Edchat. J. Res. Technol. Educ. 2019, 51, 273-289. [CrossRef]

76. Marenzi, I.; Bortoluzzi, M.; Kalyani, R. YELL/TELL: Online Community Platform for Teacher Professional Development. In Proceedings of the EUROCALL 2016, Limassol, Cyprus, 24-26 August 2016; pp. 307-312.

Publisher's Note: MDPI stays neutral with regard to jurisdictional claims in published maps and institutional affiliations.

(C) 2020 by the authors. Licensee MDPI, Basel, Switzerland. This article is an open access article distributed under the terms and conditions of the Creative Commons Attribution (CC BY) license (http://creativecommons.org/licenses/by/4.0/). 